Artigo Original

\title{
Sustainable Urban Drainage: a brief review of the compensatory techniques of structural and non-structural measures
}

\author{
Drenagem Urbana Sustentável: breve revisão das técnicas compensatórias de medidas estruturais \\ e não estruturais
}

\section{Mariana Borges Albuquerque', Angélica Ardengue de Araújo", Carlos Eduardo Nunes Medina Martinez"', Frederico Fábio Mauad'v, Cristhiane Michiko Passos Okawav}

\section{Abstract}

The accelerated disorderly and unplanned growth of cities has had negative impacts, such as the inability of the rainwater collection network to drain the area, causing flooding. Developing sustainable urban drainage projects, integrated urban water management and compensatory techniques in urban drainage are alternatives used to reduce the negative effects of urbanization on the hydrological cycle. Planning the surface runoff of urban water should go beyond structural projects, we must consider technical, financial, political and cultural aspects, among others, which makes this process complex, although very necessary. The aim of this paper is to undertake a brief literature review presenting the main urban drainage compensatory techniques used to promote sustainable management of rainwater. It concludes that there are many compensatory techniques that can be applied to promote and make sustainable urban drainage possible, whether through structural or non-structural measures.

Keywords: Urban hydrology; Compensatory Techniques in Urban Drainage; LID

\section{Resumo}

O crescimento acelerado das cidades de forma desordenada e sem planejamento vem acarretando impactos negativos, tais como a incapacidade da rede coletora de águas pluviais de realizar a drenagem da área, provocando alagamentos. Desenvolver projetos sustentáveis de drenagem urbana, gestão integrada de águas urbanas e técnicas compensatórias em drenagem urbana, são alternativas que aplicadas para diminuir o efeito negativos da urbanização ao ciclo hidrológico. Planejar o escoamento superficial das águas urbanas deve ir além de projetos estruturais, têmse que considerar aspectos técnicos, financeiros, políticos e culturais, entre outros, que faz com que esse processo seja complexo, embora bastante necessário. O objetivo desse trabalho é realizar uma breve revisão de literatura apresentando as principais técnicas compensatórias de drenagem urbana, usadas para promover um manejo sustentável das águas pluviais. Pode-se concluir que existem muitas técnicas compensatórias que podem ser aplicadas para promover e tornar possível a drenagem urbana sustentável, seja por medidas estruturais ou não estruturais.

Palavras-Chave: Hidrologia urbana; Técnicas compensatórias em Drenagem Urbana; LID 


\section{Introduction}

The process of constructing cities, especially when this occurs in a disordered, accelerated way, results in a substantial increase in the waterproofing of surfaces, in which pervious surfaces with a high capacity of infiltration in the soil are exchanged for highways, roofs and pavements, as well as increased flow speed (TUCCI, 2007; JACOBSON, 2011; LIU et al., 2015).

This change in volume and speed leads to negative impacts, such as the inability of the rainwater collection network to drain the area, causing flooding. If a river passes through the urban environment, it may also overflow.

Flooding causes damage to public and private property, encourages the chances of waterborne disease epidemics (such as cholera, typhoid, leptospirosis), as well as the loss of human life.

Some alternatives have been proposed to minimize the negative impacts of urbanization on the hydrological cycle, such as the development of sustainable urban drainage projects, the promotion of integrated urban water management and compensatory techniques in urban drainage (LIAO et al., 2013; DIETZ, 2007).

A common way of achieving this goal is by including devices that allow the infiltration of rainwater, such as infiltration ditches, winter gardens, ecological sidewa$1 \mathrm{ks}$, pervious pavements and bioretention, among others (QIN, LI, FU, 2013; JIA et al., 2015).

However, selecting the best management practices (BMP) for planning urban runoff control should consider technical aspects and financial, political and cultural aspects, among others, which makes this process complex, albeit much needed (JIA et al., 2015).

Another important factor to consider is the diffuse pollution that reaches water bodies from storm sewers. The organic load and the sediment load associated with the flow velocity can have significant impact on water bodies (AHIABLAME, SHAKYA, 2016), influencing management of water resources.

Therefore, it is essential to conduct in-depth studies of soil waterproofing and the occurrence of intense rain and interactions with the environment, as well as the generation of surface runoff that should be drained by the rainwater networks already designed for the city, in both quantitative and qualitative terms.

In this context, the aim of this work is to carry out a brief literature review presenting the main urban drainage compensatory techniques used to promote sustainable management of rainwater.

\section{Materials and Methods}

According to Gil (2008), this is exploratory research, as it provides the researcher with greater familiarity with the problem, especially due to bibliographical research on the topic of Sustainable Urban Drainage. Also according to the same author, bibliographic research is developed based on already elaborated material, consisting mainly of books and scientific articles.
The searches were conducted using the Web of Science database and considered articles from the last twenty years, in Portuguese and English, with the terms "sustainable urban drainage" and "Low Impact Development - LID”. Books on the subject were also consulted.

\section{Results and Discussion}

\subsection{Urbanization and its effect on the hydro- logical cycle}

Waterproofing of the soil, in addition to causing increased runoff, overloads the pre-existing drainage system, increasing the runoff velocity, reducing flood spikes, increasing peak flow, and reducing recharge flow of the water table (ENOMOTO, 2004).

Figure 1 shows the effect of urbanization on surface runoff. As land use changes, pervious areas in the rural environment are replaced with impervious areas, such as buildings, asphalt, and sidewalks existing in urban areas. Consequently, the hydrograph (on the right), which represents water volume over time, also changes, with higher peaks, that is, larger volumes in a shorter time interval.

Figure 1 - Effect of urbanization on runoff rate

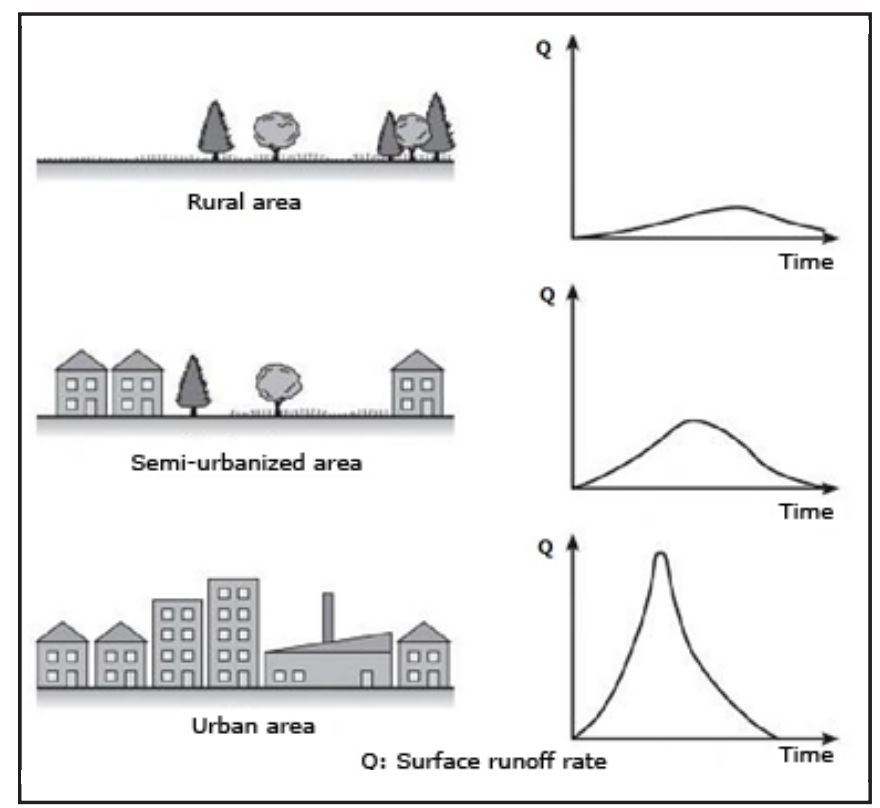

Source: Adapted from Butler \& Davies (2004).

Figure 2 shows the approximate percentages of the phases of the hydrological cycle in scenarios with and without urbanization. It can be seen that, of the total precipitation (100\%), in a scenario without urbanization, about $40 \%$ evapotranspirates, $10 \%$ flows across the surface and $50 \%$ infiltrates. In the scenario with urbanization, $15 \%$ is intercepted by roofs and channelled to storm sewers, $25 \%$ evapotranspirates, $30 \%$ infiltrates and $30 \%$ flows across the surface, but channelled, which increases flow velocity. 
Figure 2 - changes arising from urban growth

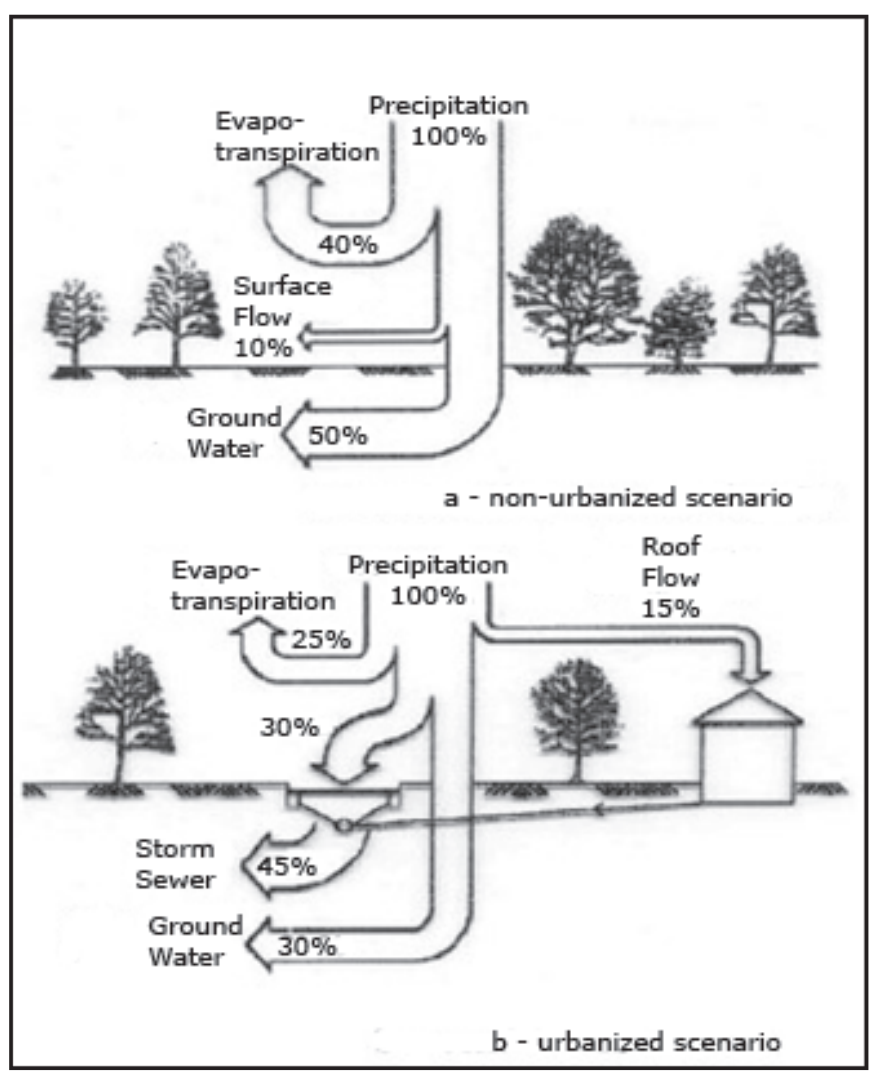

Source: Adapted from Tucci (2002)

According to Tucci (2003), other practices accompanied by the urbanization of Brazilian metropolises have aggravated changes in the balance of the hydrological cycle of the hydrographic basin. One such was deforestation and changes to vegetation cover, causing a decrease in evapotranspiration, plant interception and the natural protection the soil received against erosion. The consequences of these actions are changes to the hydrological cycle, the climate, the water balance and silting up of rivers and canals.

Another aggravating action that causes an increase in urban flooding, according to Tucci (2003), is inadequate disposal of the solid waste produced in the basin. These materials obstruct the flow of rainwater, reducing the effectiveness of the channels and conduits, clogging hydraulic structures.

\subsection{Control measures for overflows and ur- ban flooding}

Beginning in the 1960s, certain countries began to question the urban drainage system that had been used up until then. The system has construction works to drain the volume of water from important areas quickly, but this practice only transfers the problem to other areas and also to the future (POMPÊO, 2000).

The principle of this system, which still predominates, is that efficient urban drainage is one that quickly drains accumulated rainwater downstream, without taking into account the downstream overload (TUCCI, 2007).
With the insufficiency of this system, used in intense episodes of rain, investments were made to modernize and expand the pre-existing system. However, it was realized that high investment was needed to implement these changes, which were unsustainable. Thus, alternative control measures emerged for flooding episodes.

In the mid-1970s, the concept of alternative techniques of urban drainage arose. The techniques were aimed at compensating for hydrological impacts caused by urbanization, using sustainable precepts (VALLE, 2016).

These techniques applied to urban drainage were designed to maintain the naturalness of the drainage, to reduce the impact downstream, compensating for part of the urbanization effects (MELO et al, 2014).

According to Tucci (1995), the principles for controlling urban floods are: analyze the river basin as a system, the measures chosen may not reduce the impact in one area to the detriment of another; consider control measures in the basin as a whole; have an Urban Master Plan, Federal, Municipal and State Legislation, and the Drainage Manual to implement measures; avoid amplifying natural floods; permanently monitor, considering violation of the legislation; analyze the expansion horizon; educate the population by raising awareness; manage maintenance and control, and include standards.

The author goes on to say that the ways of effecting flow control measures can be by infiltrating and percolating the water, creating a space for the fluid to infiltrate; by storage, keeping part of the retained surface runoff; by increasing the efficient flow surface; pumping stations and levees to control the flood site, used in areas that do not have space for flood dampening.

Thus, over time, compensatory techniques emerged through different approaches, such as Low Impact Development (LID) and Sustainable Urban Drainage Systems (SUDS). LID, created by the United States, is a set of techniques that aggregates techniques present in Best Management Practices (BMPs), the purpose of which is low-impact urban development (SOUZA et al, 2005).

Best Management Practices are adopted in the United States and Canada aiming to control industrial and municipal effluents, and manage rainwater, controlling overflow and with treatment techniques (RIBEIRO, 2014).

LID has been identified as the best sustainable urban drainage method, since it is compatible with pre-existing drainage systems, has high efficiency, low cost, solves the problem close to the origin, proposes different forms of water use and ameliorates environmental impacts (CRUZ et al., 2007).

Although there is an incentive program for Sustainable Urban Drainage in Brazil, created by the Ministry of Cities in 2006 (BRASIL, 2006), the results of which can be seen in the various cities that use LID techniques, the pursuit of these alternatives is very low in Brazil.

According to Pereira (2016), to incentivize the search for low-impact solutions to rainwater control, a kind of tax or penalty could be created for businesses whose practices are not effective, while rewarding businesses that have been successful.

Control measures for urban flooding are divided 
into two types: structural measures and non-structural measures, with or without the concept of sustainability.

Structural measures are engineering constructions that aim to reduce volume and/or remove pollutants from the runoff. Enomoto (2004) argues that these measures are fundamental to solving most of the existing problems of urban flooding, but in addition to being costly, they do not resolve for themselves effectively and sustainably the most complex problems of urban drainage. The author goes on to say that, in order to achieve good solutions to these problems, there must be a more integrated understanding of the urban environment and the relationships between the systems of which it is comprised.

These measures can be applied with or without the concept of sustainability. For example, measures usually adopted in Brazil include "unsustainable" structural measures, such as: changing the drainage network, constructing parallel channels, placing gabions on river banks to protect against erosion or energy sinks in storm sewers, among others. There are also structural measures that come within the concept of sustainability, according to Valle (2016). These include: constructing infiltration trenches and rain gardens, constructing micro-reservoirs and cisterns, green roofs and pervious pavements, among others.

Non-structural measures seek to prevent and reduce damages through actions, legislation, standards and programs, among others, which propose disciplines for the use and occupation of urban land and the awareness of the population regarding the drainage system (KAWATOKO , 2012).

Some non-structural measures: control of urban land use, regulation for areas under construction, implementation of green areas, control of clandestine connections, sweeping streets, control of collection and final disposal of solid waste, and educating the population (FCTH, undated).

\subsection{Low-impact structural measures}

\section{- Infiltration trenches}

According to Ohnuma Jr. (2008), infiltration trenches are structures that store rainwater for a certain time, subsequently promoting the infiltration of this volume through the soil. These structures, which longer than they are wide, should be used downstream when the surface flow is accelerated due to surface waterproofing.

Figure 3 shows how infiltration trenches receive the volume of rain water. Upon reaching the impervious surface, the rainwater flows along the surface until it reaches the infiltration trenches.

To implement infiltration trenches, it is not necessary to use a large area, but the slope of this area should be considered, as in areas with steep slopes, the efficiency of such devices is reduced. In operation, these systems encourage the temporal rearrangement of hydrograms, reduced surface runoff and recharged water table, but, when not used with sufficient maintenance, the soil used in the trenches can clog and groundwater pollution may occur (VALLE, 2016).
Figure 3 - Use of infiltration trench for storing rainwater

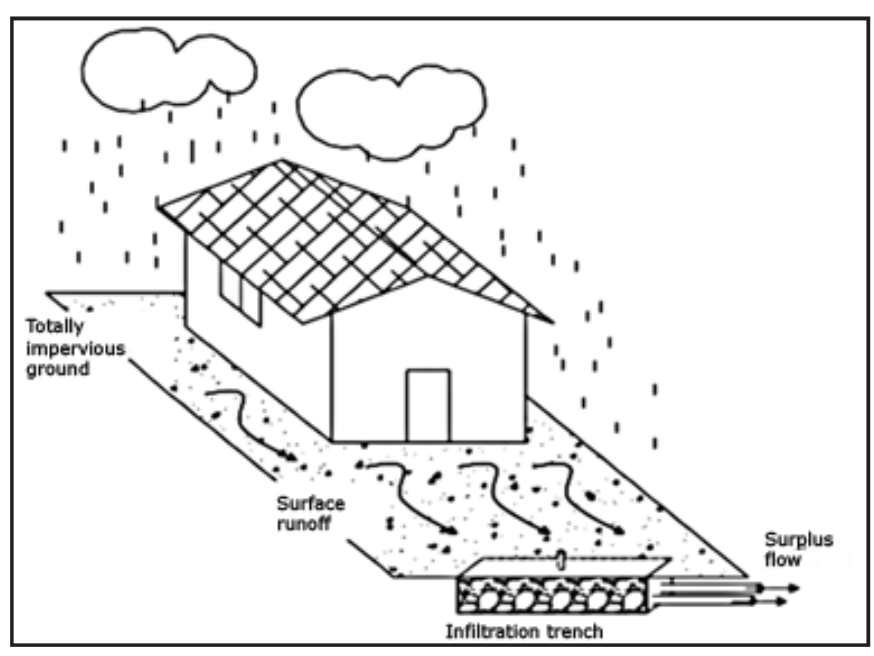

Source: Adapted from Ohnuma Jr (2008)

- Rain gardens

Rain gardens (Figure 4), also known as Bioretention Systems, utilize the biological activity of microorganisms and vegetation to eliminate pollutants from the water, and these devices infiltrate and promote rainwater retention. According to Pereira (2011), these structures are formed by depressions of the earth, can be obtained naturally or manmade, and receive the water from the surface runoff of nearby areas that have been waterproofed.

In addition to contributing to the local landscape, such structures also reduce surface runoff and remove fine sediments, metals and heavy sediments present in rainwater. As in infiltration trenches, when using this system, it must be taken into account that the soil may clog, so regular maintenance is of paramount importance, as is pre-treatment if the area suffers from high sedimentation. Before deciding on the rain garden as the system to be used in a place, it should be considered that a space of $5 \%$ of the contribution area will be necessary, and they cannot be used in very large contribution areas or in places with certain space limitations (FCTH, undated).

According to the author, applications suitable for rain gardens would be places with wide streets without heavy traffic, courtyards and parking lots, broad sidewalks, in lots (commercial, residential or public) and in streets close to places where vehicles must reduce their speed (schools, hospitals and residential neighborhoods).

- Micro-reservoirs or cisterns

According to Tominaga (2013), these devices allow temporary storage of rainwater and encourage the infiltration of the stored volume. Furthermore, according to the author, the can be implemented superficially or at shallow depths.

The operation of a micro-reservoir is shown in Figure 5 , and it can be seen that the volume precipitated onto a waterproofed surface, such as the roof shown in this figure, is drained through the pipe and sent to the micro-reservoir, which stores it up to its maximum capacity, thus releasing the surplus to the main drainage system. 
Figure 4 - Examples of application of rain gardens

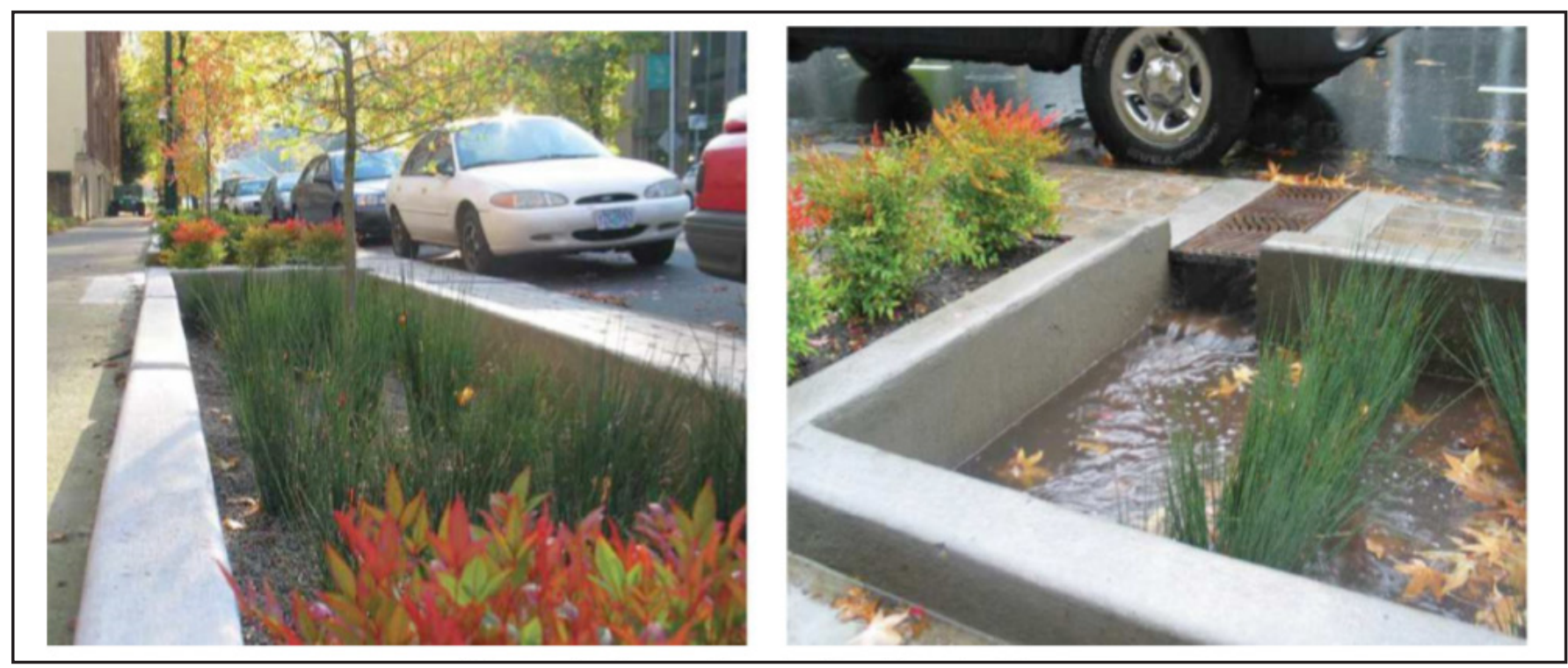

Source: FCTH (undated)

Figure 5 - Representation of how a micro-reservoir functions

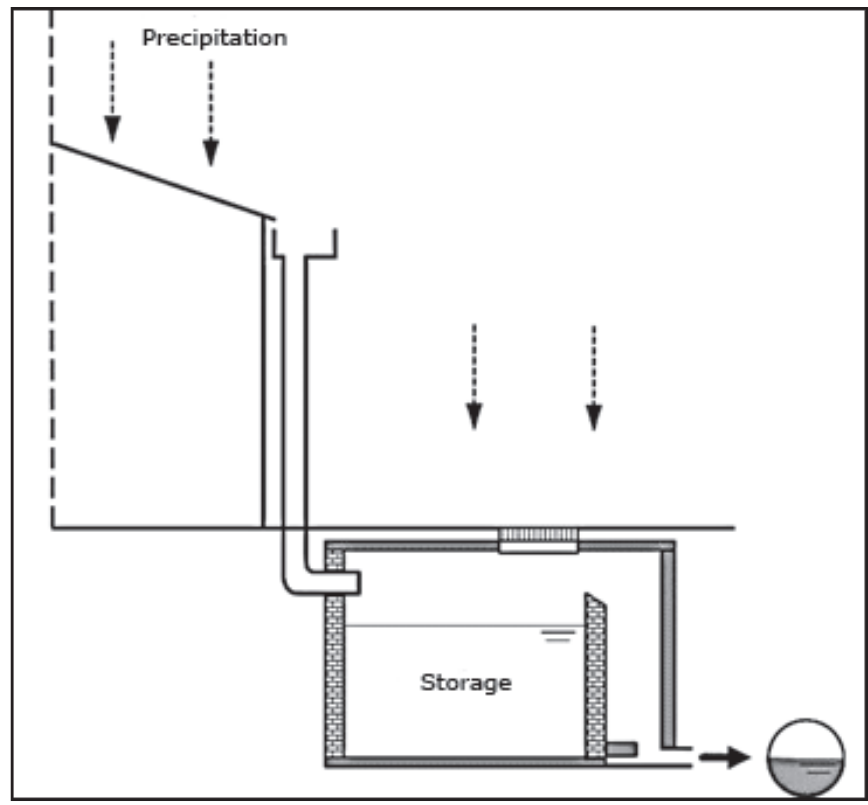

Source: Adapted from Tominaga (2013)

Just as the aforementioned structures require periodic maintenance, micro-reservoirs and cisterns also lack this maintenance over time. These devices, according to Valle (2016), besides contributing to damping the peak flood of rain episodes, relieving the drainage system downstream, allow reuse of the stored volume, for protection against fire, irrigation of vegetation or cooling of environments among others. Although these reservoirs, when buried, need a small area, the cost to implant them is considered high when compared to the other measures.

- Green roofs

Green roofs, also known as storage roofs, are structures capable of temporarily retaining the volume of water precipitated, thus promoting attenuation of flood peaks and reducing runoff volume. The volume retained during rain episodes is released to the drainage system slowly, avoiding overloading the drainage system. Moreover, the vegetation in these devices encourages the evapotranspiration of a small part of the stored rainwater, returning the volume of water to the atmosphere (TOMINAGA, 2013).

These structures can be easily integrated into landscaping projects, as can be seen in Figure 6, showing examples of application of green roofs. In addition to contributing to the appearance of the buildings, they provide them with thermal protection, thus reducing energy consumption for cooling and heating environments.

However, in order to implement this measure, the structural stability of the building, local climatic characteristics and the vegetation to be used must be considered. According to Valle (2016), structural stability must be evaluated because, in some cases, roofs are applied in buildings without account the structural projects taking this additional load promoted by the green roof into account; making the design of a structural reinforcement project necessary for the pre-existing structure. Local climatic characteristics should be considered when choosing the vegetation to be inserted, with roots that do not compromise the system, due to the different way plants adapt to climates and, if the region suffers from periods of drought, an alternative method of irrigation of vegetation.

Green roofs, Valle (2016) says, retain rainwater, thus allowing a temporal rearrangement of the hydrograms and reducing the volume of the surface runoff, such as the other devices mentioned above.

These roofs, the size of which limits the volume that can be stored, may be flat or with some slope (always less than 5\%) according to Baptista et al. (2005). 
Figure 6 - Examples of green rooves

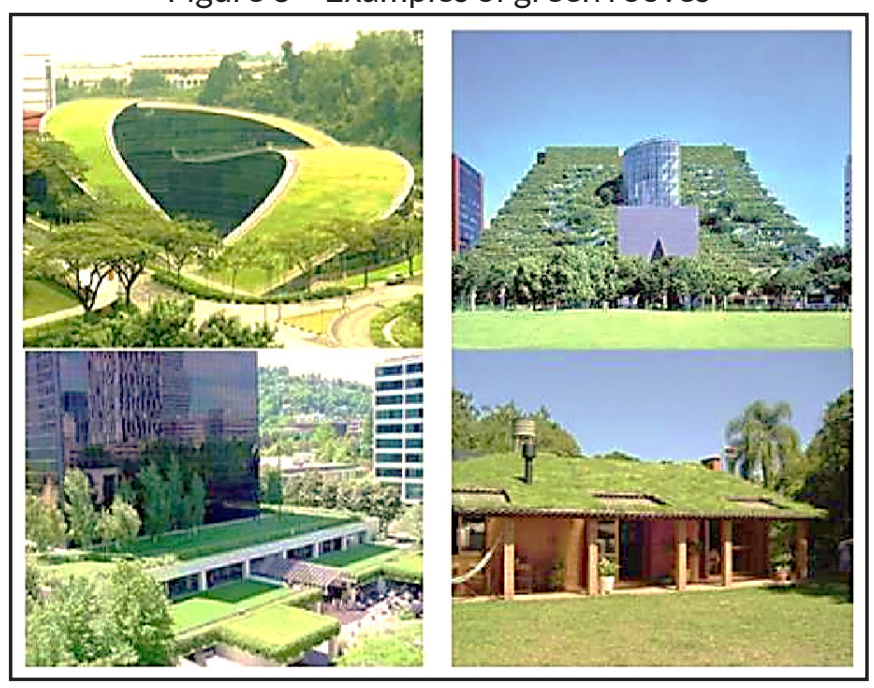

Source: Valle (2016)

Green roofs structures can be seen in Figure 7, in this design the first layer is vegetation, accompanied at its base with a substrate layer, a geotextile blanket and a drainage layer. In sequence, after the drainage layer, a layer is inserted that promotes the protection of the roof structure, thus avoiding damage to it.

- Infiltration wells

This system works in a similar way to infiltration trenches, however they are vertical rather than linear. According to Baptista et al. (2005), these structures can be fed with rainwater from the surface, with direct surface runoff, or through capture using a system of rainwater conduits. The storage capacity of this structure is low, so it is usually used as a complement to other existing control measures and not as the main measure.

Figure 8 shows the operating scheme of an infiltration well in which the water is directed to the rolled pebble layer, passing later through the geotextile layer to retain all the fine material present in this fluid. The volume that will undergo infiltration is surrounded by a geotextile blanket and porous material.

In addition to occupying little space, it reduces surface runoff, such as the other mentioned systems. Infiltration wells are less effective when used in areas of high slope, require regular maintenance due to soil clogging, may contaminate groundwater and have a low storage capacity (TOMINAGA, 2013).

- Pervious or porous pavement

Using these systems promotes the retention and infiltration of the rainwater volume, thus contributing to the control of surface flooding. In addition, the structure has high capacity of removal of soluble and particulate pollutants present in the water (TOMINAGA, 2013).

Pervious pavement has high porosity and perviousness, influencing the local hydrology where it is implanted. Porous pavement has less empty space and a low infiltration rate, however, the two types of pavements contribute to the reduction of the waterproofing of spaces that have undergone this process (VIRGILIS, 2009).

Figure 7 - Green roof structure

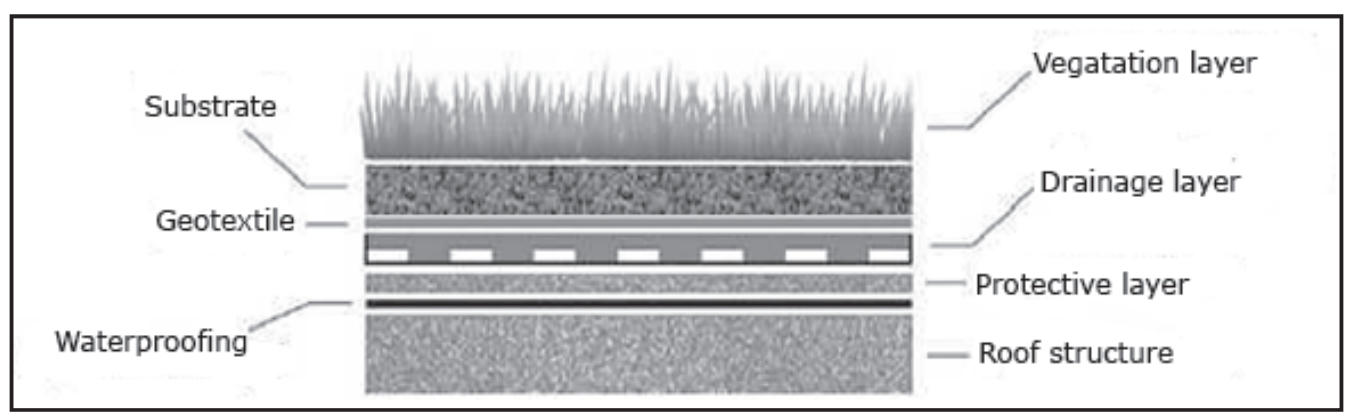

Source: Adapted from Tassi et al. (2014)

Figure 8 - Infiltration Well

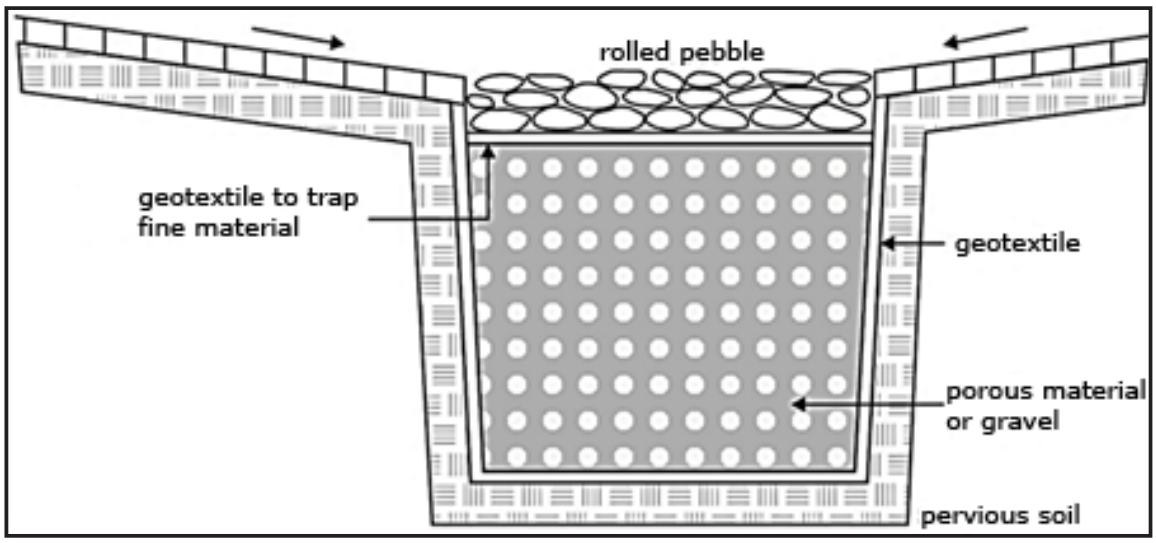

Source: Adapted from Valle (2016) 
According to Valle (2016), the materials used to construct these floors are diversified, such as: porous concrete, this type of pavement is suitable for places with low traffic, sidewalks, residential parking lots among others; interlocking blocks of concrete, as shown in the first image in Figure 9, are durable, economical and resistant, allowing traffic of various types; concrete asphalt, as shown in the second image of Figure 9, is like conventional asphalt concrete, but pervious; and the cast blocks, shown in the third image of Figure 9, are economical, durable and can bear loads.

According to Tominaga (2013), this device, which does not require an exclusive space, promotes temporary water holding; increases safety due to the reduction of the formation of puddles; recharges groundwater; and reduces the costs of drainage system deployment. However, although there are several benefits to deploying these pavements, the use of these structures can promote soil clogging, which, when it occurs, is expensive to repair; and like the other measures presented, it needs regular maintenance and specialized manpower.

- Vegetated drainage ditches

According to Tominaga (2013), vegetated ditches are simple devices, as shown in Figure 10, consisting of depressions excavated in the soil that temporarily store rainwater, encouraging infiltration and retention of pollutants.

Like other structural measures, vegetated ditches do not need a specific space for their implantation, since the storage area can also serve as a parking lot, without affecting pedestrians or vehicles, and promote reductions in the volume of surface runoff, temporary detention of water, buffering of tributaries and temporary rearrangement of hydrographs without the need for high investment. While there are several benefits to use vegetated ditches, there is a risk of groundwater pollution, water stagnation with public health implications and limited efficiency when used in areas of steep slope. In addition to these complications, implantation of this device requires adequate space for implantation and maintenance should be performed regularly (VALLE, 2016).

\subsection{Non-structural low impact measures}

According to the non-structural measures presented by Enomoto (2004), FCTH (undated) and Kawakoto (2012), the main non-structural measures that can be used to control urban flooding are described in items $A$ through $F$.

- Hydrological Property Tax

It is a way of including hydraulic and hydrological variables in the "traditional" Property Tax calculation, thus incentivizing the increase of the permeability of urban lots in exchange for payment of a Hydrological Property Tax, which is lower compared to the traditional Property Tax. It also makes it possible to negotiate the lot for another in the opposite situation.

Figure 9 - Interlocked concrete blocks, pre-shaped cast and porous asphalt concrete
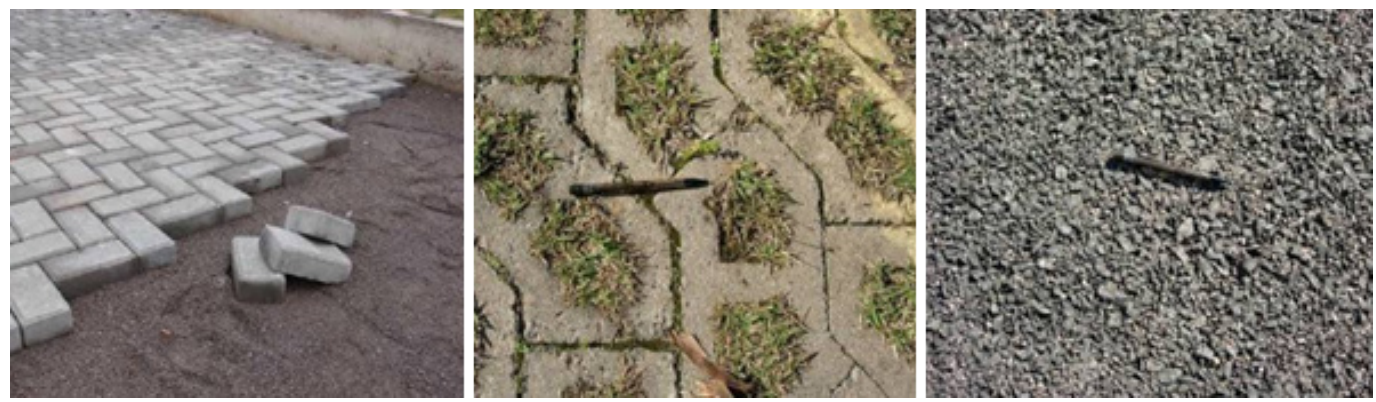

Source: Virgilis (2009)

Figure 10 - Diagram of operation of vegetated ditches

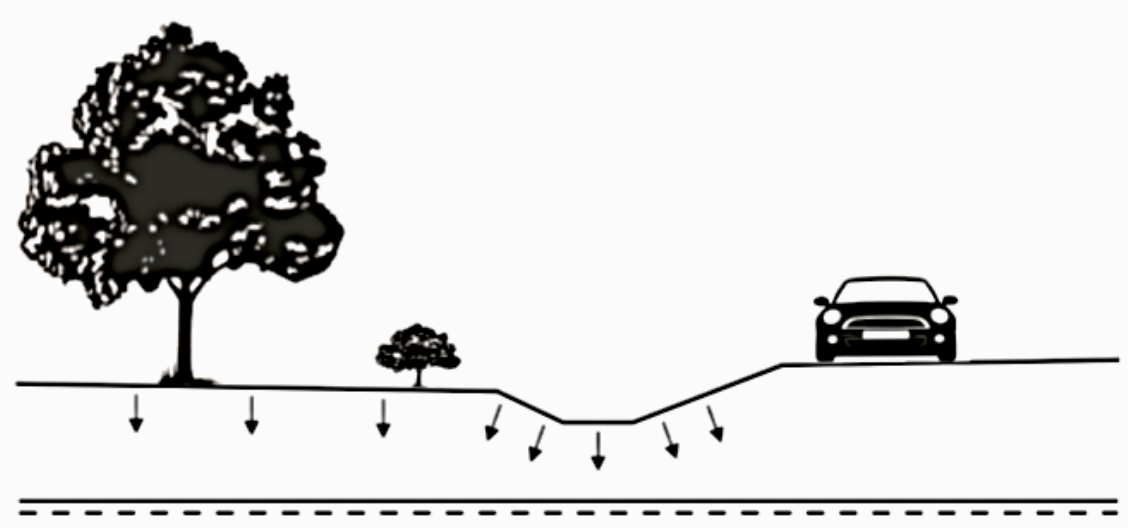

Source: Tominaga (2013) 
- Control of land use in urban areas

Through a master plan, land use control policies should be developed, avoiding unplanned occupation of urban areas, thus ensuring free spaces, reduced impermeable area and a more coherent distribution of occupancy densities. Incorporated into the master plan, zoning must be undertaken, imposing rules for the occupation of areas classified as areas at greater risk of flooding, avoiding losses of property or life.

- Establishing green areas in urban areas

Incentivizing the urban forestry of cities, as well as controlling deforestation, prevents silting and soil erosion. In addition to urban forestry, there should be incentives for the maintenance and creation of green areas, as these reduce flows and volumes of surface runoff.

- Environmental education and waste management

Educational campaigns to raise awareness and clarify doubts for the population regarding disposal of solid waste. It presents the problems that the bad disposal can entail and shows suitable disposal for each type of waste. To do this, the campaign must provide means to apply what has been taught, such as selective waste collection programs.

- Information for the population

Improve external assistance, enabling the population to learn to prevent flood episodes in the long term. For short-term prevention, in events that occur more rarely, an alert system should be inserted that can target the population of the incident.

- Resettlement and flood insurance

In areas that are subject to flood risk, legal and illegal residents are relocated to safe areas, avoiding loss of property and life. When it is not possible to prevent the episodes and to carry out resettlement, flood insurance should be given to the families affected.

\section{Concluding Remarks}

Promoting more sustainable urban drainage is possible because, as shown in this article, there are many compensatory techniques that can be applied in the urban environment, in the form of either structural or non-structural measures.

For future studies, it is suggested that a river basin of a city be chosen in order to study alternatives of compensatory techniques that could be applied to promote sustainable urban drainage. It is also possible to model the conventional urban drainage network by inserting the chosen compensatory techniques and verifying the benefit due to the decreased volume and velocity of the resulting surface runoff.

\section{Acknowledgment}

The second and third authors thank the Brazilian National Council for Scientific and Technological Development - CNPq for the financial support for their master's research.

\section{References}

AHIABLAME L, SHAKYA R. Modeling flood reduction effects of low impact development at a watershed scale. Journal of Environmental Management. 2016;171:81-91.

BAPTISTA M, NASCIMENTO N, BARRAUD S. Técnicas Compensatórias em Drenagem Urbana. 2 $2^{-}$Edição Revisada. Porto Alegre: ABRH, 2005.

BRASIL. Programa Drenagem Urbana Sustentável. Manual para apresentação de propostas. (Brasil): Ministério das Cidades; 2006.

BUTLER, D, DAVIES, JW. Urban drainage. 3rd ed ed. London ; New York: Spon Press, 2011.

CRUZ MAS, SOUZA CF, TUCCI CEM. Controle da drenagem urbana no Brasil: avanços e mecanismos para a sustentabilidade. Associação Brasileira de Recursos Hídricos. In: Anais do XVII Simpósio Brasileiro de Recursos Hídricos [Internet]; 2007 Novembro 2529; São Paulo, Brasil. 2007 [cited 2017 june]. Available from: https://abrh.s3.sa-east-1.amazonaws.com /Sumarios/19/931f07c4c229bbc1b9c1603fa24b7e12_6826f37881689 d 99197 a e f 832 b 946486 .pdf.

DIETZ ME. Low Impact Development Practices: A Review of Current Research and Recommendations for Future Directions. Water Air Soil Pollut. 2007;186:351-363.

ENOMOTO CF. Método para elaboração de mapas de inundação: estudo de caso na bacia do rio Palmital, [dissertation]. Curitiba: Setor de Tecnologia/Universidade Federal do Paraná; 2004

FCTH, Fundação Centro Tecnológico de Hidráulica. Projeto técnico: jardins de chuva [Internet]; 2017 [cited 2017 Aug 11] Available from: http://solucoesparacidades. com.br/

GIL AC. Como elaborar projetos de pesquisa. 4. ed. São Paulo: Atlas; 2008.

JACOBSON C. Identification and quantification of the hydrological impacts of imperviousness in urban catchments: A review. Journal of Environmental Management. 2011;92:1438-1448

JIA Z, TANG S, LUO W, LI S, ZHOU M. Small scale green infrastructure design to meet different urban hydrological criteria. Journal of Environmental Management. 2015;171:92-100.

KAWATOKO IES. Estabelecimento de cenários de medidas estruturais e não estruturais para gestão das águas urbanas em escala de lote [dissertação]. São Carlos: Escola de Engenharia de São Carlos/USP; 2012.

LIAO ZL, HE Y, HUANG F, WANG S, LI HZ. Analysis 
on LID for highly urbanized areas' waterlogging control: demonstrated on the example of Caohejing in Shanghai. Water Science \& Technology. 2013;68:2559-2567.

LIU Y; AHIABLAME LM, BRALTS VG, ENGEL BA. Enhancing a rainfall-runoff model to assess the impacts of BMPs and LID practices in storm runoff. Journal of Environmental Management. 2015;147:12-23.

MELO TAT, COUTINHO AP, CABRAL JJSP, ANTONINO ACD, CIRILO JA. Jardim de chuva: sistema de biorretenção para o manejo das águas pluviais urbanas. Ambiente Construído. 2014;14:147-165.

OHNUMA JÚNIOR AA. Medidas não convencionais de reservação d'água e controle da poluição hídrica em lotes domiciliares [thesis]. São Carlos: Escola de Engenharia de São Carlos/USP. 2008. 306 p.

PEREIRA FF. Sustentabilidade urbana no campus: Por uma gestão eficiente das águas pluviais. Proceedings of the VI Encontro Nacional e IV Encontro Latino-americano sobre Edificações e Comunidades Sustentáveis. 2011 sep 7-9; Vitória, ES, Brasil.

PEREIRA PP. Aplicação de indicadores para avaliação ambiental preliminar de fundos de vale na cidade de Maringá [dissertation]. Maringá: Programa de PósGraduação em Engenharia Urbana/UEM; 2016. 131 p.

POMPÊO, CA. Drenagem urbana sustentável. Revista Brasileira de Recursos Hídricos. 2000;5:15-23.

QIN H, LI Z, FU G. The Effects of Low Impact Development on Urban Flooding Under Different Rainfall Characteristics. Journal of Environmental Management. 2013;129:577-585

RIBEIRO AM. BMP's em drenagem urbana aplicabilidade em cidades brasileiras [dissertation]. São Paulo: Escola Politécnica/USP ‘ 2014. 104 p.

SOUZA CF, TUCCI CEM, POMPÊO, CA. Diretrizes para o estabelecimento de loteamentos urbanos sustentáveis. In: Anais do VI Encontro Nacional de Águas Urbanas. CREA-MG. 2005 may 18-20. Belo Horizonte, MG, Brasil.

TASSI R, TASSINARI LCS, PICCILLI DGA, PERSCH CG. Telhado verde: uma alternativa sustentável para a gestão das águas pluviais. Associação Nacional de Tecnologia do Ambiente Construído. Ambiente Construído. 2014;14:139-154.

TOMINAGA ENS. Urbanização e cheias: medidas de controle na fonte [dissertação]. São Paulo: Escola Politécnica/USP; 2013. 137 p.

TUCCI CEM. Gerenciamento da drenagem urbana. RBRH

- Revista Brasileira de Recursos Hídricos. 2002;7:5-27
TUCCI CEM. Inundações urbanas. ABRH - Associação Brasileira de Recursos Hidricos/RHAMA. 1ª edição. 2007.

TUCCI CEM, PORTO R, BARROS MT. Drenagem Urbana, Editora da Universidade/UFRGS-ABRH, Porto Alegre, 1995.

VALLE RA. Aplicação de conceitos de desenvolvimento de baixo impacto (LID) para novos loteamentos: diretrizes para a legislação municipal [dissertation]. Maringá: Programa de Pós-Graduação em Engenharia Urbana/UEM; 2016. 166 p.

VIRGILIS ALC. Procedimentos de projeto e execução de pavimentos permeáveis visando retenção e amortecimento de picos de cheias [dissertation]; São Paulo: Escola Politécnica/USP. 2009. 191 p. 